\title{
Latest Comprehensive Knowledge of the Crosstalk between TLR Signaling and Mycobacteria and the Antigens Driving the Process
}

\author{
Jae-Sung Kim ${ }^{1,2 \dagger}$, Ye-Ram Kim ${ }^{1,2 \dagger}$, and Chul-Su Yang ${ }^{1,2 *}$ \\ ${ }^{1}$ Department of Molecular and Life Science, Hanyang University, Ansan 15588, Republic of Korea \\ ${ }^{2}$ Depatment of Bionano Technology, Hanyang University, Seoul 04673, Republic of Korea
}

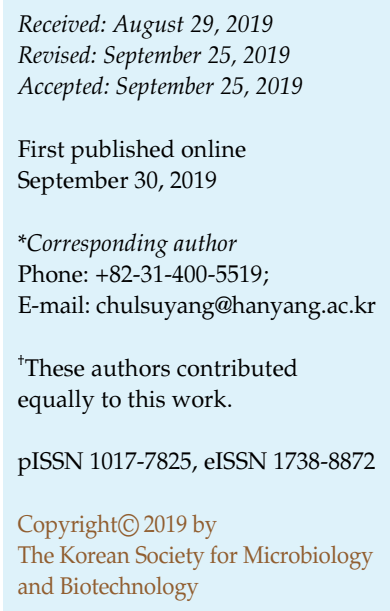

\begin{abstract}
Tuberculosis, which is caused by Mycobacterium tuberculosis (Mtb), is among the most pressing worldwide problems. Mtb uniquely interacts with innate immune cells through various pattern recognition receptors. These interactions initiate several inflammatory pathways that play essential roles in controlling Mtb pathogenesis. Although the TLR signaling pathways have essential roles in numerous host's immune defense responses, the role of TLR signaling in the response to Mtb infection is still unclear. This review presents discussions on host-Mtb interactions in terms of Mtb-mediated TLR signaling. In addition, we highlight recent discoveries pertaining to these pathways that may help in new immunotherapeutic opportunities.
\end{abstract}

Keywords: Toll-like receptors, Mycobacterium tuberculosis, innate immunity, cytokine, immunomodulatory regulator, immunotherapies

\section{Introduction}

Humans are exposed to countless, potentially pathogenic microbes through contact, ingestion, and inhalation. Host defenses against invading pathogens activate the immune system, which comprises acquired and innate immunities. If the host does not properly respond to invasion by these pathogens, serious infectious diseases can develop. Tuberculosis (TB), caused by Mycobacterium tuberculosis $(\mathrm{Mtb})$, has been prevalent since a long time and is one of the most common infectious disease. In 2017, TB caused approximately 1.3 million deaths among individuals without HIV infection as well as 300,000 deaths among patients with HIV infection [1, 2]. Mtb is a successful intracellular bacterium that has co-evolved over the years within its hosts. These features of Mtb depend on the immediate activation of innate immunity. Recent studies regarding genetic polymorphisms and related innate immunity factors support the significant roles of these factors in Mtb pathogenesis [3-5]. Host innate immune cells, including dendritic cells (DCs), macrophages, natural killer cells, and neutrophils, interact with various mycobacterial components. These cells express various pattern recognition receptors (PRRs) including C-type lectin receptors, Toll-like receptors (TLRs), RNA helicase retinoic acid-inducible gene I, and Nod-like receptors, all of which play roles in uptake and recognition [6]. Mtb has pathogen-associated molecular patterns (PAMPs) that are identified through PRRs on innate immune cells. However, Mtb can evade immune systems via several intricate mechanisms. In addition, TB-related problems have been identified a recognized in the past, but their severity has been more recently emphasized because of emerging antibiotic resistance in Mtb and the risk of re-infection [7]. There is an urgent need to develop effective treatments for TB considering various aspects such as treatment duration, potential drug toxicity, and drug-drug interactions [8]. To devise a novel strategy against $\mathrm{TB}$, it is necessary to understand the mechanisms by which Mtb is recognized by the host immune system. This review outlines the role of interaction between the TLR pathway and TB pathogenesis in innate immunity and provides an update on TLR signaling during Mtb infection. The findings revealed that the TLR pathway is a new immunotherapeutic target for the development of TB treatments. 


\section{Role of the Innate Immune System during Mtb Infection}

Mtb can escape antimicrobial immune responses [9] and interrupt the crosstalk between acquired and innate immunities [10]. Mtb has unique interactions with host immune systems, especially with immediate innate immune [11]. The primary innate immune cells participating in Mtb infection are macrophages, neutrophils, DCs, and natural killer cells. PRRs expressed on innate immune cells recognize PAMPs present in Mtb and play a critical role in the induction of innate immune responses [12]. Furthermore, other nonimmune cell types have also been revealed to contribute to host immune responses during Mtb infection. Specifically, macrophages have critical roles in mycobacterial pathogenesis because they are the major hosts for the survival of Mtb during both early and chronic infection [13]. Phagocytosis of Mtb is facilitated through a number of receptors, including complement receptors, mannose receptors, dendritic cellspecific intracellular adhesion molecule-3-grabbing nonintegrin, surfactant protein A receptors, class A scavenger receptors, and mannose-binding lectin [14, 15]. After phagocytosis, host defense systems initiate various strategies for eliminating $\mathrm{Mtb}$ such as activating proinflammatory responses [16, 17], producing reactive intermediates such as ROS and reactive nitrogen species [18], and inducing cell death to inhibit the spread of Mtb infection [19]. Conversely, Mtb also has several strategies to disturb these defenses, such as interference with phagosomal maturation and acidification, resistance to oxidative stresses, escape to the cytosol, formation of granulomas, and modulation of host cell death [9, 20]. Mtb can inhibit host innate immune systems by producing cellular envelope glycolipids and tetra-acylated sulfolipids, which are antagonists of TLR2, thereby inhibiting its role in pathogen recognition [21].

\section{TLR Biology}

Human Toll is homologous to Drosophila Toll, which exists in 10 types (TLR1-TLR10), whereas in mice, it consists of 12 types (TLR1-TLR9 and TLR11-TLR13). Similar to Drosophila Toll, human Toll is also a type I transmembrane protein containing an extracellular domain comprising a leucine-rich repeat domain and a cytoplasmic domain termed the Toll/IL-1R (TIR) domain that exhibits high similarity to the IL-1R family. The extracellular leucine-rich repeat domain is responsible for recognizing and binding PAMPs, which are conserved molecules that are essential for pathogen survival. Dimerization of TLRs results from ligand binding, which triggers the recruitment of adaptor proteins to the intracellular TIR domain. Vertebrate TLRs are classified using sequence homology into six families, namely TLR1 $(1,2,6,10)$, TLR3, TLR4, TLR5, $\operatorname{TLR} 7(7,8,9)$, and TLR11 $(11,12,13)$. Cell surface TLRs include TLR1, TLR2, TLR4, TLR5, TLR6, and TLR10, whereas intracellular TLRs include TLR3, TLR7, TLR8, TLR9, TLR11, TLR12, and TLR13 in endosomes and lysosomes. The cell surface TLRs mainly recognize microbial membrane components, whereas the other TLRs, located on intracellular vesicles, recognize microbial nucleic acids [12, 22, 23].

Upon the recognition of a ligand, the cytoplasmic TIR domain of TLRs interacts with several signaling adaptors such as myeloid differentiation primary response protein 88 (MyD88), TIR domain-containing adaptor inducing IFN$\beta$ (TRIF), TIRAP/MAL, and TRAM [24]. Various kinases (Interleukin-1 receptor-associated kinase (IRAK)4, IRAK1, IRAK2, TBK1, and inhibitor of NF- $\mathrm{B}$ kinase $\varepsilon$ ) and ubiquitin ligases (TNF receptor associated factor (TRAF) 6 and Pellino 1) are recruited and activated. The recognition of PAMPs by TLRs occurs via two signaling pathways: MyD88-dependent and TRIF-dependent pathways. The adaptor protein MyD88 serves as an essential "hub" in TLR signaling, and it associates with most TLRs. Activation of MyD88-dependent pathways triggers the phosphorylation of transforming growth factor (TGF)- $\beta$-activated kinase- 1 , which then activates three distinct pathways involving the inhibitor of NF- $\mathrm{kB}$ kinase complex and MAPKs: ERK, JNK, and p38 pathways. Consequently, this activation mediates translocation of the transcription factors activator protein 1 and NF- $\kappa$, which then induce the expression of inflammatory cytokines $[25,26]$. The TRIF-dependent pathway is specific to only a few TLRs such as TLR3 and TLR4. TRIF interacts with TRAF6 and TRAF3. The TRAF6 downstream pathway activates the transforming growth factor- $\beta$-activated kinase (TAK) 1 complex, which induces the activation of NF- $\mathrm{BB}$ and MAPKs. In the case of TRAF3, this pathway induces interferon-regulatory factor 3 phosphorylation, and then phosphorylated interferonregulatory factor 3 forms a dimer that serves as a transcription factor in the nucleus, in which it induces the expression of type I IFN genes [27]. When these pathways are excessively activated and respond to immune stimuli in a dysregulated manner, the host experiences a severe inflammatory condition [28] (Fig. 1). 


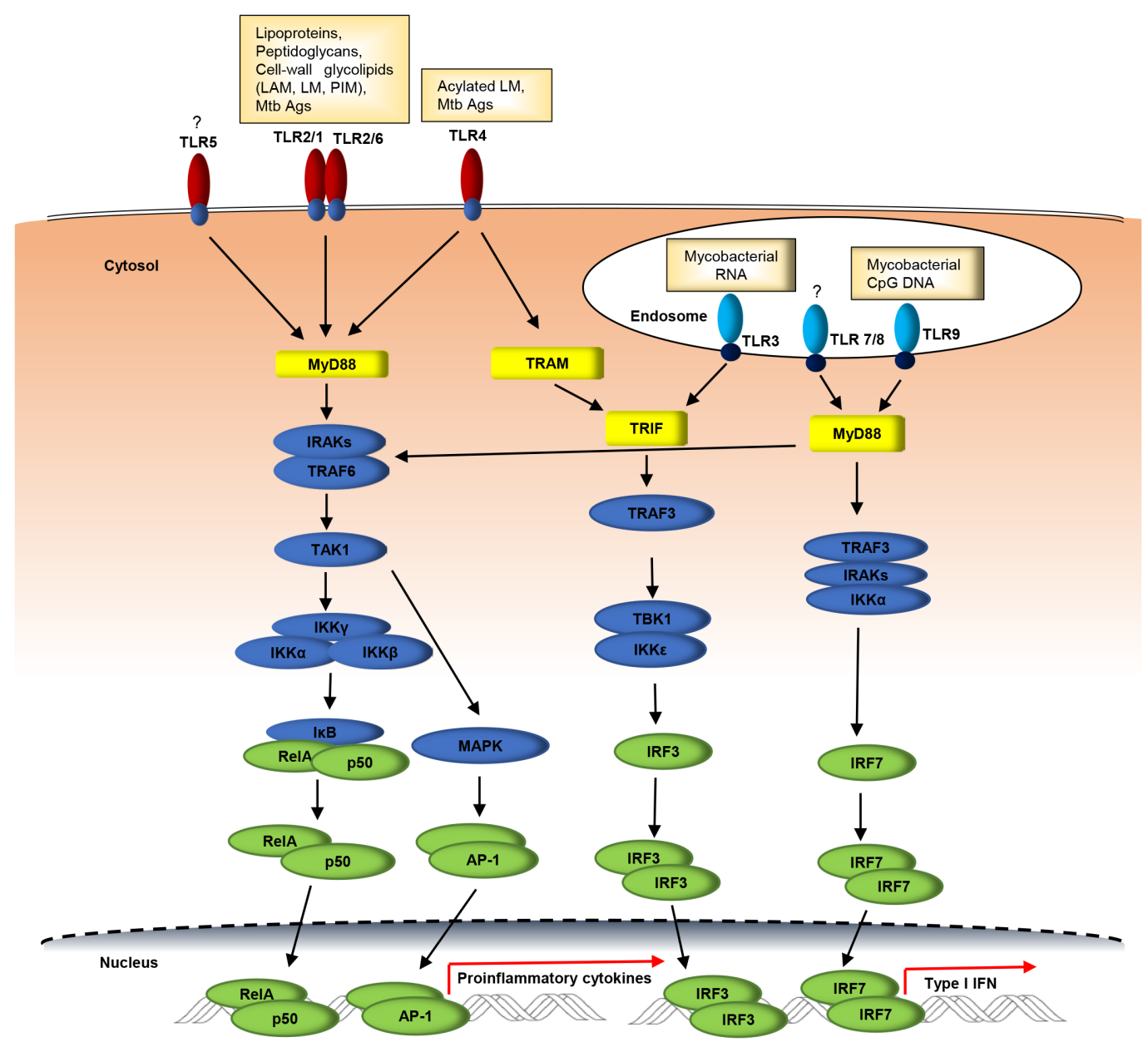

Fig. 1. A scheme of TLR signaling pathways related to mycobacterial recognition.

TLRs are involved in the innate immune response to various mycobacterial ligands (Shown in box). TLR2 and TLR1 or TLR2 and 6 and TLR5 colocalize at the cell surface, at which they sense their respective ligands, whereas TLR3, TLR7, TLR8, and TLR9 are located in endosomes, in which they recognize microbial or host-derived nucleic acids. Only TLR4 is expressed on both the cell surface and in endosomes (not shown in the figure). Stimulation of TLR1/2 by mycobacterial ligands leads to the engagement of Toll/IL-1R (TIR) domain-containing adaptor proteins (either myeloid differentiation primary-response protein 88 [MyD88] or TIR domain-containing adaptor protein inducing IFN $\beta$ [TRIF] and TRIF-related adaptor molecular [TRAM]). Engagement of the adaptor molecules activates downstream signaling pathways that involve associations between IL-1R-associated kinases (IRAKs) and the adaptor molecules TNF receptor-associated factors (TRAFs), followed by activation of MAPKs, which in turn activate transcription factors. These major transcription factors are NF-kB (RelA/p50), activator protein 1 (AP1), and interferon-regulatory factors (IRFs). A major result of the activation of extracellular TLRs is the induction of pro-inflammatory cytokines such as IL-6, TNF- $\alpha$, and IL-1 $\beta$. However, a major consequence is the induction of IRFs, leading to the production of type I IFN $\alpha$ and IFN $\beta$. LAM, Lipoarabinomannan; LM,

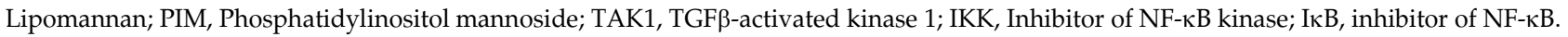

\section{Interaction between the TLR Pathway and Mycobacteria}

Several studies suggested that TLRs are essential factors for Mtb infection. Despite a number of studies revealing a critical role of TLR signaling in mycobacterium detection in vitro, the in vivo significance of TLRs remains unclear [14, 29]. In particular, TLR1, TLR2, TLR6, TLR9, and possibly
TLR4 are the key receptors involved in the recognition of mycobacterial infection. In this part, we introduce studies discussing the role of the TLR pathway against mycobacterial infection (Table 1).

\section{TLR2}

TLR2, forming heterodimers with TLR1 or TLR6, is a 
Table 1. The roles of TLRs in mycobacterial infection.

\begin{tabular}{|c|c|c|c|}
\hline TLR & Function & Bacteria & Ref. \\
\hline \multirow[t]{4}{*}{ TLR2 } & Induction of pro-inflammatory cytokines & Mtb & [35-37] \\
\hline & Induction of ROS generation, chemokine production, and MAPK activation & Mtb & {$[38,39]$} \\
\hline & Reduction of bacterial burden & Mtb & [40-42] \\
\hline & Reduction of neutrophil-derived inflammation by regulating CXCL5 production & Mtb & [43] \\
\hline \multirow[t]{2}{*}{ TLR3 } & Induction of IL-10 via the PI3K/AKT signaling pathway & BCG & [46] \\
\hline & Progression of infection through activation of TLR3 pathway using poly (I:C) & Mtb & {$[47,48]$} \\
\hline \multirow[t]{3}{*}{ TLR4 } & Induction of phagocytosis & Mtb & [53] \\
\hline & Induction of pro-inflammatory cytokine & Mtb, BCG & {$[54,55,61]$} \\
\hline & Control of the balance cell death & Mtb & {$[63]$} \\
\hline TLR7 & Induction of killing bacteria through autophagy & Mtb & [64] \\
\hline \multirow[t]{2}{*}{ TLR9 } & Induction of pro-inflammatory cytokines & Mtb & [37] \\
\hline & Induction of Th1 response and Th1-associated cytokine IFN- $\gamma$ & Mtb & [72] \\
\hline
\end{tabular}

well-known receptor that is involved in recognition and response by innate immune cells including macrophages and DCs. In particular, TLR2 is the central receptor involved in the recognition of mycobacteria. Stimulation of TLR2 by mycobacterial ligands is important for inducing the intracellular signaling that activates the NF- $\mathrm{BB}$ and MAPK pathways. These pathways trigger the production of pro-inflammatory cytokines and chemokines and induce phagocytosis, the killing of $\mathrm{Mtb}$, and antigen presentation. TLR2 mainly recognizes a variety of mycobacterial cell wall antigens such as lipoarabinomannan, lipomannan (LM), 38- and 19-kDa mycobacterial lipoprotein, phosphatidylinositol mannoside, and triacylated (TLR2/ TLR1) or diacylated (TLR2/TLR6) lipoproteins [30-34]. In a previous study, TLR2 was demonstrated to be essential for the expression of pro-inflammatory cytokines, as inhibition of TLR2 expression in Raw 264.7 macrophages inhibited TNF- $\alpha$ expression in response to Mtb infection [35]. In addition, an important role for TLR2 and TLR6 was found in the production of IL-1 $\beta$ through the MyD88 pathway during $\mathrm{Mtb}$ infection [36]. IL-12 release in macrophages and DCs is also dependent on TLR2 in response to $\mathrm{Mtb}$ infection [37]. ROS generation is also induced by TLR2, and it is important for the MAPK pathway-dependent expression of CXCL8 and CCL2 in human primary monocytes [38]. In human DCs, TLR2 also induces ROS production to stimulate DC maturation and lymphocyte proliferation in response to Mtb [39]. The role of TLR2 was also indicated through an in vivo study in which TLR2 KO mice, but not TLR6 KO mice, exhibited reduced Mtb clearance and granuloma formation in the lungs and enhanced susceptibility to Mtb infection. TLR2- deficient mice also display decreased pro-inflammatory cytokine production [40-42]. In TLR2 KO mice, Mtb increases the bacterial burden and disturbs the control of neutrophilic inflammation. TLR2 downregulates CXCL5 production to prevent neutrophil-mediated pathology during Mtb infection [43]. In addition, TLR2 cooperates with other TLR family including TLR4 [44] and TLR9 during Mtb infection. Despite published supports, several murine studies revealed that TLR2 is not essential for host protection against acute Mtb infection [41, 42, 45].

\section{TLR3}

The role of TLR3, a sensor of extracellular viral or host RNA derived from infected or damaged cells, in TB pathogenesis has not been elucidated. A recent study revealed that mycobacterial RNA-induced IL-10 production is regulated by TLR3 through PI3K/AKT. Upon Mycobacterium bovis bacillus Calmette-Guérin (BCG) infection, TLR $3^{-/-}$mice exhibited reduced IL-10 production but elevated IL-12 production compared with the findings in controls as well as inhibited AKT phosphorylation. In addition, BCG-infected $\mathrm{TLR}^{-/-}$mice exhibited reduced pulmonary bacterial burden and tissue damage [46]. However, the evidence supporting the link between TLR3 and TB outcome remains controversial. TLR3 pathway stimulation using agonist poly (I:C) led to increased bacterial load and mycobacterial growth. Intranasal poly (I:C) treatment aggravates lung pathology and increases bacterial growth in H37Rv-infected mice through type I IFN [47, 48]. Nevertheless, poly (I:C) is being studied as a candidate for a vaccine against TB. TLR3 stimulation 
through poly (I:C)-encapsulating nanoparticles enhances the pro-inflammatory immune response to BCG-infected macrophages in a synergistic manner [49]. A novel liposome adjuvant, dimethyl dioctadecyl ammonium bromide combined with poly (I:C) and cholesterol (DPC), can play a role in Mtb subunit vaccine development. In this case, poly (I:C) could attenuate disease severity following Mtb infection in mice [50].

\section{TLR4}

TLR4 is well known for recognizing endotoxins produced by gram-negative bacteria such as LPS [51]. Although some earlier studies focused on the TLR2 pathway, recent investigations uncovered evidence of the critical role of the TLR4 pathway in mycobacterial infection [52]. The TLR4 signaling pathway plays various essential roles in Mtb infection. LPS, a TLR4 ligand, upregulates TLR4/NADPH oxidase complex 2 expression and increases ROS levels. Blockade of TLR4 using anti-TLR4 receptor antibody and the endotoxin antagonist E5531 inhibits the killing of Mtb by macrophages and TLR4dependent Mtb-induced pro-inflammatory responses [53, 54]. TLR4 recognizes cell wall lipids, glycoproteins, and antigens in Mtb. Acylated forms of M. bovis BCG LM modulate inflammatory activities via the TLR4 signaling pathway in macrophages [55]. Upregulation of TLR4 in response to Mtb infection has also been noted, with the surface of expression of both TLR4 and TLR2 on lymphocytes in patients with TB being significantly higher than that in healthy control individuals [56, 57]. These results confirmed that the expression of TLR4 on CD14+ monocytes, but not TLR2, is upregulated in individuals who received BCG vaccines compared with the findings in unvaccinated individuals [58]. In the case of neutrophils, Mtb stimulation also induces the expression of TLR4, TNF$\alpha$, and scavenger receptors [59, 60]. Another study demonstrated that TLR4 expression is required to protect mice against chronic Mtb infection. TLR4-mutant $\mathrm{C} 3 \mathrm{H} / \mathrm{HeJ}$ mice have higher susceptibility to $\mathrm{H} 37 \mathrm{Rv}$ infection than wild-type mice. TLR4-mutant mice cannot induce inflammatory responses properly upon exposure to endotoxins or $\mathrm{Mtb}[57,61]$, but other results found no significant difference in susceptibility between wild-type and TLR4-mutant mice [43, 62]. TLR4-dependent signals play an essential role in the maintenance of the balance between apoptotic and necrotic cell death upon H37Rv infection [63]. Despite accumulating evidence from the aforementioned studies, several investigations have questioned the importance of TLR4 in mycobacterial infection in vivo $[41,62]$. Further studies are necessary to identify the role of TLR4 in mycobacterial infection.

\section{TLR7 and TLR8}

TLR7 and TLR8 mainly recognize ssRNA. In many studies, they were found to be related to intracellular infection such as viral infection. The ligands of TLR7 and TLR8 in Mtb are unclear. However, some studies found that TLR7 is also involved in Mtb infection. In macrophages, TLR7 expression is upregulated by Mtb. TLR7 is important for cell viability and the induction of autophagy [64]. In addition, TLR8 expression is increased in THP-1 macrophages after BCG infection [65]. In a clinical study, TLR7 and TLR8 genetic polymorphisms were linked to increased susceptibility to Mtb infection with high phagocytosis $[65,66]$. TLR8 agonists play roles in protecting against Mtb challenge in TLR8 transgenic mice. Regarding immunization, ESAT-6 antigen has a better effect in combination with a TLR8 agonist [67].

\section{TLR9}

TLR9 recognizes bacterial DNA [68, 69], possibly including Mtb DNA, activates macrophages to induce proinflammatory responses [70], and induces T-cell differentiation [71]. TLR9 has a protective role against Mtb infection in combination with TLR2. TLR2/TLR9 ${ }^{-/-}$mice displayed markedly high susceptibility to Mtb infection in associated with defective IL-12 p40 and IFN $\gamma$ production, but in the presence of TLR2, TLR9 ${ }^{-/-}$mice exhibited only minor reductions in resistance compared with the findings in double gene-deficient mice [72]. Several recent investigations demonstrated that TLR9 is associated with Mtb infection. One study identified the immunomodulatory mechanism of vitamin D using heliotherapy in TB via the upregulation of TLR9 [73]. Accumulating genetic evidence indicates that particular TLR9 polymorphisms might portend a higher risk for TB [74-76].

\section{Diverse Functions of TLRs in Response to Mtb Antigens}

Antigens from pathogens are of considerable interest for use in vaccine development and the diagnosis of infectious diseases including TB [77]. In particular, Mtb has a variety of antigens because it has unique cell walls and it secretes 
Table 2. Mycobacterial antigens that regulate TLRs signaling pathway.

\begin{tabular}{|c|c|c|c|c|c|}
\hline TLR & Antigen & Characteristic & Function & Cell Type & Ref. \\
\hline \multirow[t]{20}{*}{ TLR2 } & Rv1737c & DosR & $\begin{array}{l}\text { Induction of TLR2 expression and macrophages } \\
\text { activation }\end{array}$ & Macrophage & [122] \\
\hline & LpqT & Lipoproteins & $\begin{array}{l}\text { Suppression of activation of MAPK pathway, } \\
\text { MHC II antigen processing. } \\
\text { Induction of apoptosis }\end{array}$ & Macrophage & {$[84,85]$} \\
\hline & LprG & Lipoproteins & $\begin{array}{l}\text { Suppression of MHC II antigen processing, } \\
\text { Induction of pro-inflammatory cytokines }\end{array}$ & Macrophage & {$[85,86]$} \\
\hline & LprA & Lipoproteins & $\begin{array}{l}\text { Suppression of MHC II antigen processing, } \\
\text { Induction of pro-inflammatory cytokines }\end{array}$ & Macrophage & [87] \\
\hline & $\begin{array}{l}\text { 19-kDa Antigens } \\
(\mathrm{LpqH})\end{array}$ & Lipoproteins & $\begin{array}{l}\text { Suppression of MHC II antigen processing } \\
\text { Induction of pro-inflammatory cytokines, activation of } \\
\text { MAPK pathway, apoptosis }\end{array}$ & Macrophage & {$[91,92]$} \\
\hline & MPT83 & $\begin{array}{l}\text { Secreted } \\
\text { lipoproteins }\end{array}$ & $\begin{array}{l}\text { Induction of activation of MAPK and NF- } \mathrm{kB} \text { pathway, } \\
\text { pro-inflammatory cytokines, apoptosis. } \\
\text { Enhancement of APC function }\end{array}$ & Macrophage & {$[93,94]$} \\
\hline & Lipomannan & $\begin{array}{l}\text { Cell wall } \\
\text { component }\end{array}$ & $\begin{array}{l}\text { Induction of activation of MAPK and NF- } \mathrm{kB} \text { pathway, } \\
\text { pro-inflammatory cytokines, granuloma macrophage } \\
\text { fusion }\end{array}$ & Macrophage & [95-97] \\
\hline & Lipoarabinomannan & $\begin{array}{l}\text { Cell wall } \\
\text { component }\end{array}$ & $\begin{array}{l}\text { Induction of activation of MAPK and NF- } \mathrm{kB} \text { pathway, } \\
\text { pro-inflammatory cytokines, granuloma macrophage } \\
\text { fusion }\end{array}$ & Macrophage & [98] \\
\hline & PE_PGRS11 & $\begin{array}{l}\text { PE family } \\
\text { protein }\end{array}$ & $\begin{array}{l}\text { Induction of activation of MAPK and NF-kB pathway. } \\
\text { Suppression of ROS generation }\end{array}$ & $\begin{array}{l}\text { Endothelial } \\
\text { cell }\end{array}$ & [100] \\
\hline & PE_PGRS33 & $\begin{array}{l}\text { PE family } \\
\text { protein }\end{array}$ & $\begin{array}{l}\text { Induction of activation of MAPK and NF-kB pathway, } \\
\text { apoptosis }\end{array}$ & Macrophage & {$[101,102]$} \\
\hline & PE_PGRS62 & $\begin{array}{l}\text { PE family } \\
\text { protein }\end{array}$ & $\begin{array}{l}\text { Induction of activation of MAPK and NF-kB pathway } \\
\text { Suppression of pro-inflammatory cytokines }\end{array}$ & $\begin{array}{l}\text { Dendritic } \\
\text { Cell, } \\
\text { Macrophage }\end{array}$ & {$[103,104]$} \\
\hline & PPE17 & $\begin{array}{l}\text { PPE family } \\
\text { protein }\end{array}$ & $\begin{array}{l}\text { Induction of activation of MAPK and NF-KB pathway, } \\
\text { pro-inflammatory cytokines }\end{array}$ & Macrophage & [105] \\
\hline & PPE18 & $\begin{array}{l}\text { PPE family } \\
\text { protein }\end{array}$ & $\begin{array}{l}\text { Induction of activation of MAPK and NF- } \mathrm{kB} \text { pathway, } \\
\text { anti-inflammatory cytokines. } \\
\text { Suppresion of pro-inflammatory cytokines }\end{array}$ & Macrophage & {$[106,107]$} \\
\hline & PPE26 & $\begin{array}{l}\text { PPE family } \\
\text { protein }\end{array}$ & $\begin{array}{l}\text { Induction of activation of MAPK and NF- } \mathrm{BB} \text { pathway, } \\
\text { pro-inflammatory cytokines, cell surface markers, } \\
\text { T cell immunity }\end{array}$ & Macrophage & [109] \\
\hline & PPE32 & $\begin{array}{l}\text { PPE family } \\
\text { protein }\end{array}$ & $\begin{array}{l}\text { Induction of activation of MAPK and NF-kB pathway, } \\
\text { pro- and anti-inflammatory cytokines, }\end{array}$ & Macrophage & [110] \\
\hline & PPE60 & $\begin{array}{l}\text { PPE family } \\
\text { protein }\end{array}$ & $\begin{array}{l}\text { Induction of activation of MAPK and NF-kB pathway, } \\
\text { pro-inflammatory cytokines, Th1/Th17 immunity }\end{array}$ & Dendritic Cell & [111] \\
\hline & PPE68 & $\begin{array}{l}\text { PPE family } \\
\text { protein }\end{array}$ & $\begin{array}{l}\text { Induction of activation of MAPK, anti-inflammatory } \\
\text { cytokines. Suppression of pro-inflammatory cytokines }\end{array}$ & Macrophage & [108] \\
\hline & Hsp60 & $\begin{array}{l}\text { Heat shock } \\
\text { protein }\end{array}$ & $\begin{array}{l}\text { Induction of activation of MAPK, anti-inflammatory } \\
\text { cytokines. Suppression of pro-inflammatory cytokines }\end{array}$ & $\begin{array}{l}\text { Macrophage } \\
\mathrm{T} \text { cell }\end{array}$ & {$[112,113]$} \\
\hline & ChoD & $\begin{array}{l}\text { Cholesterol } \\
\text { oxidase }\end{array}$ & $\begin{array}{l}\text { Induction of activation of MAPK, anti-inflammatory } \\
\text { cytokines, ROS generation }\end{array}$ & Macrophage & [115] \\
\hline & Rv0577 & $\begin{array}{l}\text { Potential } \\
\text { glyoxylase }\end{array}$ & $\begin{array}{l}\text { Induction of activation of MAPK, pro-inflammatory } \\
\text { cytokines, DC maturation, Th1 immunity }\end{array}$ & Dendritic Cell & [116] \\
\hline
\end{tabular}


Table 2. Continued.

\begin{tabular}{|c|c|c|c|c|c|}
\hline TLR & Antigen & Characteristic & Function & Cell Type & Ref. \\
\hline \multirow[t]{9}{*}{ TLR2 } & Hip1 & Serine hydrolase & $\begin{array}{l}\text { Suppression of pro-inflammatory cytokines, DC maturation } \\
\text { and Th1/Th17 immunity }\end{array}$ & $\begin{array}{l}\text { Dendritic Cell } \\
\text { Macrophage }\end{array}$ & {$[117,118]$} \\
\hline & $\operatorname{Rv} 3529 c$ & Sulfotransferase & $\begin{array}{l}\text { Suppression of MAPK, NF-кB pathway pro-inflammatory } \\
\text { cytokines, ROS generation, phagosome-lysosome fusion }\end{array}$ & Macrophage & [119] \\
\hline & Rv0774c & Extracellular esterase & $\begin{array}{l}\text { Suppression of MAPK, pro- and anti-inflammatory } \\
\text { cytokines, NO production }\end{array}$ & Macrophage & [120] \\
\hline & Lrp & $\begin{array}{l}\text { Leucine-responsive } \\
\text { regulatory protein }\end{array}$ & $\begin{array}{l}\text { Suppression of NF- } \mathrm{BB} \text { pathway, } \\
\text { pro-inflammatory cytokines, APC function }\end{array}$ & Macrophage & [121] \\
\hline & $\operatorname{Rv} 3131$ & $\begin{array}{l}\text { FMN binding } \\
\text { nitroreductase domain- } \\
\text { containing protein }\end{array}$ & $\begin{array}{l}\text { Induction of activation of NF-кB pathway, } \\
\text { pro-inflammatory cytokines }\end{array}$ & Macrophage & [123] \\
\hline & Rv2660c & Hypothetical protein & $\begin{array}{l}\text { Induction of activation of pro-inflammatory cytokines } \\
\text { Increasing the intracellular survival of bacteria }\end{array}$ & Macrophage & [124] \\
\hline & $\operatorname{Rv} 3628$ & $\begin{array}{l}\text { Soluble inorganic } \\
\text { pyrophosphatase }\end{array}$ & $\begin{array}{l}\text { Induction of activation of MAPK and NF- } \mathrm{BB} \text { pathway, } \\
\text { pro-inflammatory cytokines, Th1 immunity }\end{array}$ & Dendritic Cell & [125] \\
\hline & DATIN & $\begin{array}{l}\text { Dormancy Associated } \\
\text { Translation Inhibitor }\end{array}$ & Induction of activation of pro-inflammatory cytokines & Macrophage & [126] \\
\hline & MymA & $\begin{array}{l}\text { 55-kDa Mtb flavin- } \\
\text { containing } \\
\text { monooxygenase }\end{array}$ & $\begin{array}{l}\text { Induction of activation of NF- } \mathrm{B} \text { pathway, } \\
\text { pro-inflammatory cytokines, Th1 immunity }\end{array}$ & Macrophage & [127] \\
\hline \multirow[t]{6}{*}{ TLR4 } & $\mathrm{Rv} 2882 \mathrm{c}$ & Secreted culture filtrate & $\begin{array}{l}\text { Induction of activation of MAPK and NF- } \kappa \text { B pathway, } \\
\text { Induction of expansion of the T-cell, } \\
\text { Improvement of protective efficacy with BCG }\end{array}$ & Macrophage & [132] \\
\hline & Rv0652 & Secreted culture filtrate & $\begin{array}{l}\text { Induction of activation of MAPK pathway and the } \\
\text { expression of surface molecules on cell, DC maturation, and } \\
\text { proinflammatory cytokine production, } \\
\text { Enhancement of the polarization of T effector cells to Th1 } \\
\text { immunity }\end{array}$ & $\begin{array}{l}\text { Macrophage, } \\
\text { Dendritic cell }\end{array}$ & {$[133,134]$} \\
\hline & GrpE & Heat shock protein & $\begin{array}{l}\text { Induction of activation of MAPK and NF-KB pathway, } \\
\text { Induction of } \mathrm{T} \text { cell proliferation }\end{array}$ & Dendritic Cell & [138] \\
\hline & $\begin{array}{l}\text { RpfB } \\
(\operatorname{Rv} 1009)\end{array}$ & $\begin{array}{l}\text { Resuscitation- } \\
\text { promoting factor }\end{array}$ & $\begin{array}{l}\text { Induction of activation of MAPK and NF-אB pathway, } \\
\text { Induction of T cell proliferation }\end{array}$ & Dendritic Cell & [139] \\
\hline & $\operatorname{Rv} 3841$ & Secreted culture filtrate & $\begin{array}{l}\text { Induction of activation of MAPK and NF-KB pathway, } \\
\text { Induction of } \mathrm{T} \text { cell proliferation }\end{array}$ & Dendritic Cell & [140] \\
\hline & HSP65 & Heat shock protein & Induction of activation of NF- $\kappa B$ pathway & $\begin{array}{l}\text { Endothelial } \\
\text { cell }\end{array}$ & [137] \\
\hline \multirow[t]{4}{*}{ TLR2/4 } & ESAT-6 & Secreted culture filtrate & $\begin{array}{l}\text { Induction of activation of MAPK, pro-inflammatory } \\
\text { cytokines, type I IFN, T cell immunity }\end{array}$ & Macrophage & [141-143] \\
\hline & $\begin{array}{l}\text { 38-kDa } \\
\text { Antigens } \\
\text { (PstS-1) }\end{array}$ & Secreted culture filtrate & Induction of activation of MAPK pathway, ER stress & Monocyte & {$[44,144]$} \\
\hline & HSP70 & Heat shock protein & Induction of activation of NF- $\kappa B$ pathway & $\begin{array}{l}\text { Endothelial } \\
\text { cell }\end{array}$ & [137] \\
\hline & $\operatorname{Rv} 3463$ & Secreted culture filtrate & $\begin{array}{l}\text { Induction of expression of surface molecules and } \\
\text { pro-inflammatory cytokines, } \\
\text { Induction of bactericidal effects via phagosome maturation }\end{array}$ & Macrophages & [145] \\
\hline
\end{tabular}


antigens following infection. Mtb antigen discovery efforts have continued for several decades, and several studies already revealed their immunogenicity for improving the design of TB vaccines [78]. Although these studies mainly focused on T-cell immune responses [79-82], the correlation between $\mathrm{Mtb}$ antigens and TLR has recently been actively studied (Table 2). Mtb antigens mainly interact with TLR2 and TLR4, with TLR2 having a dominant role.

\section{TLR2-Associated Mtb Antigens}

TLR2 is an important receptor for recognizing Mtb. Several Mtb antigens interact with TLR2. They include both cell wall components of Mtb such as lipoprotein, LM, and 38- or 19-kDa antigens and specific proteins or enzymes found only in Mtb.

\section{TLR2-Associated Mtb Lipoprotein Antigens}

LpqT is a ligand of TLR2 that suppresses MAPK and NF$\kappa \mathrm{B}$ signaling. The ligand can boost mycobacterial survival by inhibiting TLR2-dependent effects on inflammatory cytokine expression and cell apoptosis in macrophages. This lipoprotein is also involved in inhibiting major histocompatibility complex II (MHC II) antigen processing in CD4+ $\mathrm{T}$ cells to evade immune surveillance [83, 84]. LprG and LprA are also agonists that bind directly to TLR2. In macrophages, these antigens induce inflammatory cytokine expression and negatively control MHC II antigen processing to modulate inflammation [8587].

LpqH, a 19-kDa lipoprotein, also triggers TLR2 activation, leading to upregulation of the expression of death receptors and ligands that induce apoptosis. $\mathrm{LpqH}$ is also associated with the induction of autophagy-dependent TLR2/TLR1/CD14 and vitamin D3 signaling for antimycobacterial activity. $\mathrm{LpqH}$ participates in the manipulation of adaptive immunity by inducing cytokine secretion and directly regulating the activation of memory in $\mathrm{CD}^{+} \mathrm{T}$ cells [88-90]. In addition, 19-kDa lipoproteins are also well-known TLR2 ligands. These antigens induce apoptosis via the TLR2 pathway in macrophages. In addition, TLR2-mediated PPAR $\gamma$ expression is induced by $19-k D a$ lipoproteins, thereby promoting inflammatory responses by activating the MAPK pathway [91, 92]. Additionally, 19-kDa lipoproteins are involved in IFN- $\gamma$ signaling. IFN- $\gamma$ signaling is associated with the expression of class II transactivator, which regulates chromatin remodeling. 19-kDa lipoproteins inhibit IFN- $\gamma$ signaling and class II transactivator expression through the TLR2 pathway.

The secreted mycobacterial protein MPT83 is involved in immune responses via the TLR2 pathway. This protein induces pro-inflammatory cytokine production and apoptosis by activating the MAPK and NF- $\mathrm{B}$ pathways. However, MHC II antigen processing is inhibited by MPT83 [93, 94]. Both of these components are recognized by TLR2, and they activate the immune responses of innate immune cells.

\section{TLR2-Associated Mtb Lipomannan Antigens}

LM has been reported to induce the expression and secretion of matrix metalloproteinase 9 in macrophages through a TLR1/TLR2- and CD14-mediated pathway [95, 96]. Furthermore, LM is associated with granulomamacrophage fusion via a TLR2-dependent pathway that is mediated by $\beta_{1}$ integrin/ADAM9[97]. Lipoarabinomannan also interacts with TLR1 and TLR2 signaling pathways and induces signals that activate inflammation [98].

The proline-glutamic acid (PE) and proline-prolineglutamic acid (PPE) gene family members are only found in Mtb. Many studies indicated that PE or PPE proteins are related to various immune responses.

PE family proteins feature a particular PE region. Some PE family protein has multiple copies of polymorphic guanine-cytosine-rich sequences (PGRSs), and they are referred to as PE_PGRS family proteins. Many PE_PGRS proteins are related to the cell wall, and they can be recognized by TLR2. In addition, PE_PGRS proteins can induce the maturation and activation of immune cells by upregulating MAPK and NF- $\mathrm{B}$ signaling [99]. PE_PGRS11 plays a role in regulating resistance to oxidative stress. PE_PGRS11 downregulates $\mathrm{H}_{2} \mathrm{O}_{2}$-mediated p38 MAPK signaling and increases the survival of bacteria [100]. PE_PGRS33, a surface-exposed protein, interacts with TLR2 and induces the release of TNF- $\alpha$ by activating MAPK signaling in macrophages. This causes the release of cytochrome c, leading to the activation of apoptosis [101, 102]. PE_PGRS62 binds to TLR2 and attenuates the expression of IL-1 $\beta$, IL-6, and iNOS in macrophages [103, 104].

PPE family proteins have common regions that include a PPE motif near the N-terminal region. PPE17 interacts with TLR2 and activates NF- $\mathrm{B}$ signaling. In a clinical study, an Mtb-infected patient was easily infected by HIV-1 because PPE17 augments transcription, leading to HIV-1 LTR transactivation [105]. PPE18 and PPE68 can induce the activation of MAPK via TLR2, and they are important for 
the induction of IL-10 expression in macrophages. Interestingly, recombinant PPE18 proteins can attenuate inflammation and enhance survival in sepsis [106-108]. PPE26 and PPE32 trigger inflammatory responses, leading to activation of the MAPK and NF- $\kappa B$ pathways. Meanwhile, PPE26 CD4 ${ }^{+}$and Th1-type T cells are polarized by the immune response [109, 110]. PPE60 drives Th1/ Th17 responses through the TLR2-mediated maturation of DCs by activating MAPK and NF- $\mathrm{B}$ pathways [111].

Heat shock proteins (HSPs), which are molecular chaperones, are also recognized by TLR2. Hsp60 is a ligand of TLR2, and it upregulates IL-10 production to modulate the immune response. Additionally, HSP60 controls T-cell responses by regulating the surface expression of TLR2 $[112,113]$.

\section{TLR2-Associated Mtb Proteins or Enzymes Antigens}

Other enzymes or factors in Mtb can act as TLR2 ligands. The $30-\mathrm{kDa}$ antigen of $\mathrm{Mtb}$ is known as a good inducer of immune responses. It generates ROS production via TLR2. In addition, the $30-\mathrm{kDa}$ antigen upregulates the expression of CXCL8 and CCL2 [114]. ChoD, a cholesterol oxidase, also binds TLR2 and participates in immune responses. ChoD activates the MAPK pathway and stimulates the production of IL-10 [115]. Rv0577 can drive DC maturation and pro-inflammatory cytokine expression by activating MAPK and NF- $\kappa$ B pathways in a TLR2-dependent manner. In addition, Rv0577 has an important role in $\mathrm{CD} 4^{+}$and $\mathrm{CD}^{+}$T-cell polarization [116]. Hip1, a serine hydrolase, attenuates pro-inflammatory responses by inhibiting TLR2 activation. This antigen interferes with DC maturation, cytokine secretion, and antigen presentation [117, 118]. Rv3529c and Rv0774c negatively regulate TLR2-mediated pro-inflammatory responses. They suppress the production of pro-inflammatory cytokines and enhance the production of anti-inflammatory cytokines [119, 120].

Leucine-responsive regulatory protein also inhibits proinflammatory responses by disrupting NF- $\mathrm{B}$ signaling. Leucine-responsive regulatory protein activates the PI3K/ Akt pathway, which has an inhibitory effect on TLR2 [121]. Rv1737c, one of the dormancy survival regulator antigens, is mainly expressed in the latent phase of Mtb infection. Rv1737c upregulates TLR2 expression and induces NF-кB activation on macrophages in a non-TLR4-dependent manner [122]. Rv3131, an uncharacterized member of the dormancy survival regulator regulon, encodes an FMNbinding nitroreductase domain-containing protein, and it induces pro-inflammatory cytokines through the TLR2 signaling pathway. Rv3131 interacts with TLR2 and contributes to the phosphorylation of NF-кB [123]. Rv2660c and Rv3628 augment the expression of pro-inflammatory cytokines by interacting with TLR2. They enhance proinflammatory cytokines expression, leading to the activation of MAPK and NF- $\mathrm{BB}$ signaling. Rv3628 also polarizes DCs and CD4 ${ }^{+}$T cells $[124,125]$.

Dormancy-associated translation inhibitor also interacts with TLR2 and elevates the levels of pro-inflammatory cytokines [126]. MymA, a cell wall-associated protein, also increases pro-inflammatory cytokine expression, leading to the activation of MAPK and NF- $\mathrm{B}$ pathways, which are dependent on TLR2 signaling [127].

$\mathrm{Mtb}$ also releases membrane vesicles (MVs) into the environment. MVs carry virulence factors of Mtb such as phospholipids, proteins, and cell wall components. Lipoproteins are also delivered to the cell by MVs. Carried lipoproteins stimulate the TLR2 signaling pathway and then trigger an inflammatory response [128]. Another study uncovered that exosomes from Mtb-infected cells can inhibit IFN- $\gamma$ signaling after Mtb infection. These exosomes contain $\mathrm{Mtb}$ virulence factors that are delivered to macrophages $[129,130]$. The virulence factors of Mtb may modulate the immune system $[114,131]$.

\section{TLR4 Signaling Pathway-Associated Antigens}

Several studies demonstrated that Mtb-derived antigens regulate the TLR4 signaling pathway, including HSPs and culture filtrate proteins, suggesting their potential use in the development of novel vaccines [33]. Rv2882c, an Mtb culture filtrate, induces the activation of macrophages to express pro-inflammatory cytokines, co-stimulatory, and MHC via the TLR4 pathway [132]. Rv0652, another culturefiltrated antigen derived from Mtb, also activates macrophages through the TLR4 pathway and then induces pro-inflammatory responses such as the production of TNF- $\alpha$ and monocyte chemoattractant protein-1 [133]. In addition, Rv0652 is recognized via the TLR4 receptor, thereby inducing DC maturation and the production of pro-inflammatory cytokines, such as TNF- $\alpha$, IL- $1 \beta$, and IL6, through MyD88- and TRIF-dependent signaling pathways [134].

Mycobacterial HSPs have been revealed to exert several immunologic effects following Mtb infection [135, 136]. Mtb HSP65 and HSP70 induce the activation of NF- $\mathrm{kB}$ signaling and the expression of TLR4, but not functional TLR2, in human endothelial cells. In particular, HSP65 was demonstrated to signal exclusively through TLR4 [137]. Mtb GrpE, a cofactor of HSP70, induces the activation and 
maturation of DCs upon binding to TLR4 and promotes Th1-biased T-cell immune responses, as DCs from TLR4 ${ }^{-/-}$ mice exhibited no response to Mtb GrpE [138]. Similarly, RpfB is another Mtb antigen that binds to TLR4, followed by MyD88/TRIF-dependent signaling and subsequent MAPK and NF-kB activation in DCs [139]. Activation of DCs by Rv3841 (also known as Mtb ferritin B) is mediated by TLR4, followed by the induction of MAPK and NF- $\mathrm{KB}$ signaling pathways and Th1 immune responses [140].

\section{TLR2 and TLR4 Signaling-Associated Mtb Antigens}

Several studies identified Mtb antigens that require both the TLR2 and TLR4 pathways to modulate immune responses. ESAT-6, a 6-kDa secreted antigen, can bind to both TLR2 and TLR4. This antigen induces apoptosis by elevating cleaved caspase- 9 and caspase- 3 expression. ROS generation and MAPK phosphorylation also contribute to the induction of apoptosis. In addition, ESAT- 6 stimulates the expression of type 1 IFN. IFN- $\beta$ is upregulated by ESAT-6 in a TLR2 and TLR4 pathway-dependent manner. By contrast, ESAT-6 inhibits T-cell immune responses by suppressing antigen-presenting cell function [141-143].

The 38-kDa antigen (e.g., PstS-1) from culture filtrates of Mtb H37Rv activates MAPK signaling in human monocytes via TLR2 and TLR4. PstS-1 also plays important roles in the induction of endoplasmic reticulum stressmediated apoptosis via TLR2 and TLR4. MCP-1, a proinflammatory cytokine, is upregulated by $38-\mathrm{kDa}$ antigen, and ROS and endoplasmic reticulum stress levels are consequently elevated [44, 144].

Recombinant Rv3463 induces the expression of surface molecules and pro-inflammatory cytokine production through TLR2 and TLR4 pathways in macrophages. It induces MAPK, PI3K, and NF- $\mathrm{KB}$ signaling in macrophages. Also, Rv3463 sustains the active state of Mtbinfected cells and inhibits bacterial growth by enhancing phagosomal fusion [145].

\section{Conclusions and Perspectives}

TB remains a severe infectious disorder that can lead to death. The innate immune system, which plays a crucial role in the establishment of appropriate host defense mechanisms, is involved in the early phases of $\mathrm{Mtb}$ infection [146]. In this review, we comprehensively summarized recent findings about innate immune recognition by mycobacteria, particularly focusing on TLRs. Several investigations about the Mtb-host relationship have been conducted, but the involvement of various Mtb-derived PAMPs in TB-mediated immunity remains unclear. Based on several preceding investigations [147-149], we suggest that countless Mtb antigens can be potential modulators that can regulate the host immune responses including those of TLRs to regulate uncontrolled inflammatory responses. In particular, Mtb-secreted culture filtrate antigens exhibit serologic reactivity. The ability to activate inflammatory signaling cascades through the TLR pathway means that the modulation of TLR signaling could be targeted as a new treatment strategy against TB[150]. Several factors from Mtb can regulate host innate immunity by dictating a sophisticated system that relates multiple host signaling pathways such as the TLR pathway. However, activating the immune system may induce adverse events in the host, such as the development of autoimmune diseases and breakdown of host immune homeostasis. It is critical to further identify the mechanisms associated with TLR signaling in TB pathogenesis and use these results to overcome the expected effects on TLR signaling to develop promising immunotherapies for TB.

\section{Acknowledgments}

This work was supported by the research fund of Hanyang University (HY-2015-N).

\section{Conflicts of Interest}

The authors have no financial conflicts of interest to declare.

\section{References}

1. Jeon S, Lim N, Park S, Park M, Kim S. 2018. Comparison of PFGE, IS6110-RFLP, and 24-Locus MIRU-VNTR for molecular epidemiologic typing of Mycobacterium tuberculosis isolates with known epidemic connections. J. Microbiol. Biotechnol. 28: $338-346$

2. Glaziou P, Floyd K, Raviglione MC. 2018. Global epidemiology of tuberculosis. Semin. Respir. Crit. Care Med. 39: 271-285.

3. Wu S, Wang $Y$, Zhang M, Shrestha SS, Wang M, He JQ. 2018. Genetic polymorphisms of IL1B, IL6, and TNFalpha in a Chinese Han population with pulmonary tuberculosis. Biomed. Res. Int. 2018: 3010898.

4. Kim S, Seo H, Mahmud HA, Islam MI, Kim YS, Lyu J, et al. 2017. In vitro effect of DFC-2 on mycolic acid biosynthesis 
in Mycobacterium tuberculosis. J. Microbiol. Biotechnol. 27: 1932-1941.

5. Azad AK, Sadee W, Schlesinger LS. 2012. Innate immune gene polymorphisms in tuberculosis. Infect. Immun. 80: 33433359.

6. Venketaraman V. 2018. Understanding the host immune response against Mycobacterium tuberculosis Infection, pp. 23-40. Ed. Springer, Switzerland.

7. Dookie N, Rambaran S, Padayatchi N, Mahomed S, Naidoo K. 2018. Evolution of drug resistance in Mycobacterium tuberculosis: a review on the molecular determinants of resistance and implications for personalized care. J. Antimicrob. Chemother. 73: 1138-1151.

8. Kwon BE, Ahn JH, Min S, Kim H, Seo J, Yeo SG, et al. 2018. Development of new preventive and therapeutic vaccines for Tuberculosis. Immune Netw. 18(2): e17.

9. Queval CJ, Brosch R, Simeone R. 2017. The macrophage: a disputed fortress in the battle against Mycobacterium tuberculosis. Front. Microbiol. 8: 2284.

10. Mayer-Barber KD, Barber DL. 2015. Innate and adaptive cellular immune responses to Mycobacterium tuberculosis Infection. Cold Spring Harb. Perspect. Med. 5(12).

11. van Crevel R, Ottenhoff TH, van der Meer JW. 2002. Innate immunity to Mycobacterium tuberculosis. Clin. Microbiol. Rev. 15: 294-309.

12. Akira S, Uematsu S, Takeuchi O. 2006. Pathogen recognition and innate immunity. Cell 124: 783-801.

13. McClean CM, Tobin DM. 2016. Macrophage form, function, and phenotype in mycobacterial infection: lessons from tuberculosis and other diseases. Pathog Dis. 74(7).

14. Berrington WR, Hawn TR. 2007. Mycobacterium tuberculosis, macrophages, and the innate immune response: does common variation matter? Immunol. Rev. 219: 167-186.

15. Ernst JD. 1998. Macrophage receptors for Mycobacterium tuberculosis. Infect. Immun. 66: 1277-1281.

16. Ciaramella A, Cavone A, Santucci MB, Amicosante M, Martino A, Auricchio G, et al. 2002. Proinflammatory cytokines in the course of Mycobacterium tuberculosisinduced apoptosis in monocytes/macrophages. J. Infect. Dis. 186: 1277-1282.

17. Moure R, Domingo P, Gallego-Escuredo JM, Villarroya J, Gutierrez Mdel M, Mateo MG, et al. 2016. Impact of elvitegravir on human adipocytes: alterations in differentiation, gene expression and release of adipokines and cytokines. Antiviral Res. 132: 59-65.

18. Voskuil MI, Bartek IL, Visconti K, Schoolnik GK. 2011. The response of mycobacterium tuberculosis to reactive oxygen and nitrogen species. Front. Microbiol. 2: 105.

19. Amaral EP, Lasunskaia EB, D'Imperio-Lima MR. 2016. Innate immunity in tuberculosis: how the sensing of mycobacteria and tissue damage modulates macrophage death. Microbes Infect. 18: 11-20.
20. Zhai W, Wu F, Zhang Y, Fu Y, Liu Z. 2019. The Immune escape mechanisms of Mycobacterium tuberculosis. Int. J. Mol Sci. 20(2).

21. Blanc L, Gilleron M, Prandi J, Song OR, Jang MS, Gicquel B, et al. 2017. Mycobacterium tuberculosis inhibits human innate immune responses via the production of TLR2 antagonist glycolipids. Proc. Natl. Acad. Sci. USA 114: 11205-11210.

22. Seo JY, Choi JW, Lee JY, Park YS, Park YI. 2018. Enzyme hydrolysates of ginseng marc polysaccharides promote the phagocytic activity of macrophages via activation of TLR2 and Mer tyrosine kinase. J. Microbiol. Biotechnol. 28: 860873.

23. Triantafilou M, Gamper FG, Haston RM, Mouratis MA, Morath S, Hartung T, et al. 2006. Membrane sorting of tolllike receptor (TLR)-2/6 and TLR2/1 heterodimers at the cell surface determines heterotypic associations with CD36 and intracellular targeting. J. Biol. Chem. 281: 31002-31011.

24. Lim KH, Staudt LM. 2013. Toll-like receptor signaling. Cold Spring Harb. Perspect Biol. 5: a011247.

25. Irie $T$, Muta $T$, Takeshige K. 2000. TAK1 mediates an activation signal from toll-like receptor(s) to nuclear factorkappaB in lipopolysaccharide-stimulated macrophages. FEBS Lett. 467: 160-164.

26. Kawai T, Akira S. 2007. Signaling to NF-kappaB by tolllike receptors. Trends Mol. Med. 13: 460-469.

27. Kawai T, Akira S. 2010. The role of pattern-recognition receptors in innate immunity: update on Toll-like receptors. Nat. Immunol. 11: 373-384.

28. Vijay K. 2018. Toll-like receptors in immunity and inflammatory diseases: Past, present, and future. Int. Immunopharmacol. 59: 391-412.

29. Holscher C, Reiling N, Schaible UE, Holscher A, Bathmann C, Korbel D, et al. 2008. Containment of aerogenic Mycobacterium tuberculosis infection in mice does not require MyD88 adaptor function for TLR2, -4 and -9. Eur. J. Immunol. 38: 680-694.

30. Kleinnijenhuis J, Oosting M, Joosten LA, Netea MG, Van Crevel R. 2011. Innate immune recognition of Mycobacterium tuberculosis. Clin. Dev. Immunol. 2011: 405310.

31. Basu J, Shin DM, Jo EK. 2012. Mycobacterial signaling through toll-like receptors. Front. Cell Infect. Microbiol. 2: 145 .

32. Mortaz E, Adcock IM, Tabarsi P, Masjedi MR, Mansouri D, Velayati AA, et al. 2015. Interaction of pattern recognition receptors with Mycobacterium Tuberculosis. J. Clin. Immunol. 35: $1-10$.

33. Hossain MM, Norazmi MN. 2013. Pattern recognition receptors and cytokines in Mycobacterium tuberculosis infection--the double-edged sword? Biomed. Res. Int. 2013: 179174. 
34. Kawai T, Akira S. 2011. Toll-like receptors and their crosstalk with other innate receptors in infection and immunity. Immunity 34: 637-650.

35. Underhill DM, Ozinsky A, Smith KD, Aderem A. 1999. Toll-like receptor-2 mediates mycobacteria-induced proinflammatory signaling in macrophages. Proc. Natl. Acad. Sci. USA 96: 14459-14463.

36. Kleinnijenhuis J, Joosten LA, van de Veerdonk FL, Savage N, van Crevel R, Kullberg BJ, et al. 2009. Transcriptional and inflammasome-mediated pathways for the induction of IL1beta production by Mycobacterium tuberculosis. Eur. J. Immunol. 39: 1914-1922.

37. Pompei L, Jang S, Zamlynny B, Ravikumar S, McBride A, Hickman SP, et al. 2007. Disparity in IL-12 release in dendritic cells and macrophages in response to Mycobacterium tuberculosis is due to use of distinct TLRs. J. Immunol. 178: 5192-5199.

38. Lee HM, Shin DM, Kim KK, Lee JS, Paik TH, Jo EK. 2009. Roles of reactive oxygen species in CXCL8 and CCL2 expression in response to the $30-\mathrm{kDa}$ antigen of Mycobacterium tuberculosis. J. Clin. Immunol. 29: 46-56.

39. Romero MM, Basile JI, Corra Feo L, Lopez B, Ritacco V, Aleman M. 2016. Reactive oxygen species production by human dendritic cells involves TLR2 and dectin- 1 and is essential for efficient immune response against Mycobacteria. Cell Microbiol. 18: 875-886.

40. Drennan MB, Nicolle D, Quesniaux VJ, Jacobs M, Allie N, Mpagi J, et al. 2004. Toll-like receptor 2-deficient mice succumb to Mycobacterium tuberculosis infection. Am. J. Pathol. 164: 49-57.

41. Reiling N, Holscher C, Fehrenbach A, Kroger S, Kirschning CJ, Goyert S, et al. 2002. Cutting edge: toll-like receptor (TLR)2- and TLR4-mediated pathogen recognition in resistance to airborne infection with Mycobacterium tuberculosis. J Immunol. 169: 3480-3484.

42. Sugawara I, Yamada H, Li C, Mizuno S, Takeuchi O, Akira S. 2003. Mycobacterial infection in TLR2 and TLR6 knockout mice. Microbiol. Immunol. 47: 327-336.

43. Gopalakrishnan A, Dietzold J, Verma S, Bhagavathula M, Salgame P. 2019. Toll-like receptor 2 prevents neutrophildriven immunopathology during infection with mycobacterium tuberculosis by curtailing CXCL5 production. Infect. Immun. 87(3): pii: e00760-1.

44. Jung SB, Yang CS, Lee JS, Shin AR, Jung SS, Son JW, et al. 2006. The mycobacterial 38-kilodalton glycolipoprotein antigen activates the mitogen-activated protein kinase pathway and release of proinflammatory cytokines through Toll-like receptors 2 and 4 in human monocytes. Infect. Immun. 74: 2686-2696.

45. McBride A, Bhatt K, Salgame P. 2011. Development of a secondary immune response to Mycobacterium tuberculosis is independent of Toll-like receptor 2. Infect. Immun. 79: 1118-1123.
46. Bai W, Liu H, Ji Q, Zhou Y, Liang L, Zheng R, et al. 2014 TLR3 regulates mycobacterial RNA-induced IL-10 production through the PI3K/AKT signaling pathway. Cell Signal. 26: 942-950.

47. Antonelli LR, Gigliotti Rothfuchs A, Goncalves R, Roffe E, Cheever AW, Bafica A, et al. 2010. Intranasal Poly-IC treatment exacerbates tuberculosis in mice through the pulmonary recruitment of a pathogen-permissive monocyte/ macrophage population. J. Clin. Invest. 120: 1674-1682.

48. Huang L, Russell DG. 2017. Protective immunity against tuberculosis: what does it look like and how do we find it? Curr. Opin. Immunol. 48: 44-50.

49. Speth MT, Repnik U, Muller E, Spanier J, Kalinke U, Corthay A, et al. 2017. Poly(I:C)-Encapsulating nanoparticles enhance innate immune responses to the Tuberculosis vaccine Bacille Calmette-Guerin (BCG) via synergistic activation of innate immune receptors. Mol. Pharm. 14: 4098-4112

50. Liu X, Da Z, Wang Y, Niu H, Li R, Yu H, et al. 2016. A novel liposome adjuvant DPC mediates Mycobacterium tuberculosis subunit vaccine well to induce cell-mediated immunity and high protective efficacy in mice. Vaccine 34: 1370-1378.

51. Pandey S, Kawai T, Akira S. 2014. Microbial sensing by Toll-like receptors and intracellular nucleic acid sensors. Cold Spring Harb. Perspect. Biol. 7: a016246.

52. Sepehri Z, Kiani Z, Kohan F, Ghavami S. 2019. Toll-like receptor 4 as an immune receptor against Mycobacterium tuberculosis: a systematic review. Lab. Med. 50: 117-129.

53. Lv J, He X, Wang H, Wang Z, Kelly GT, Wang X, et al. 2017. TLR4-NOX2 axis regulates the phagocytosis and killing of Mycobacterium tuberculosis by macrophages. BMC Pulm. Med. 17: 194.

54. Means TK, Jones BW, Schromm AB, Shurtleff BA, Smith JA, Keane J, et al. 2001. Differential effects of a Toll-like receptor antagonist on Mycobacterium tuberculosis-induced macrophage responses. J. Immunol. 166: 4074-4082.

55. Doz E, Rose S, Nigou J, Gilleron M, Puzo G, Erard F, et al. 2007. Acylation determines the toll-like receptor (TLR)dependent positive versus TLR2-, mannose receptor-, and SIGNR1-independent negative regulation of pro-inflammatory cytokines by mycobacterial lipomannan. J. Biol. Chem. 282: 26014-26025.

56. Chang JS, Huggett JF, Dheda K, Kim LU, Zumla A, Rook GA. 2006. Myobacterium tuberculosis induces selective upregulation of TLRs in the mononuclear leukocytes of patients with active pulmonary tuberculosis. J. Immunol. 176: 3010-3018.

57. Abel B, Thieblemont N, Quesniaux VJ, Brown N, Mpagi J, Miyake K, et al. 2002. Toll-like receptor 4 expression is required to control chronic Mycobacterium tuberculosis infection in mice. J. Immunol. 169: 3155-3162. 
58. Kleinnijenhuis J, Quintin J, Preijers F, Benn CS, Joosten LA, Jacobs C, et al. 2014. Long-lasting effects of BCG vaccination on both heterologous Th1/Th17 responses and innate trained immunity. J. Innate. Immun. 6: 152-158.

59. Hilda JN, Selvaraj A, Das SD. 2012. Mycobacterium tuberculosis $\mathrm{H} 37 \mathrm{Rv}$ is more effective compared to vaccine strains in modulating neutrophil functions: an in vitro study. FEMS Immunol. Med. Microbiol. 66: 372-381.

60. Nancy Hilda J, Das S. 2018. Neutrophil CD64, TLR2 and TLR4 expression increases but phagocytic potential decreases during tuberculosis. Tuberculosis (Edinb). 111: 135-142.

61. Branger J, Leemans JC, Florquin S, Weijer S, Speelman P, Van Der Poll T. 2004. Toll-like receptor 4 plays a protective role in pulmonary tuberculosis in mice. Int. Immunol. 16: 509-516.

62. Shim TS, Turner OC, Orme IM. 2003. Toll-like receptor 4 plays no role in susceptibility of mice to Mycobacterium tuberculosis infection. Tuberculosis (Edinb) 83: 367-371.

63. Sanchez D, Rojas M, Hernandez I, Radzioch D, Garcia LF, Barrera LF. 2010. Role of TLR2- and TLR4-mediated signaling in Mycobacterium tuberculosis-induced macrophage death. Cell Immunol. 260: 128-136.

64. Bao M, Yi Z, Fu Y. 2017. Activation of TLR7 Inhibition of Mycobacterium Tuberculosis Survival by Autophagy in RAW 264.7 Macrophages. J. Cell Biochem. 118: 4222-4229.

65. Davila S, Hibberd ML, Hari Dass R, Wong HE, Sahiratmadja E, Bonnard C, et al. 2008. Genetic association and expression studies indicate a role of toll-like receptor 8 in pulmonary tuberculosis. PLoS Genet. 4: e1000218.

66. Lai YF, Lin TM, Wang CH, Su PY, Wu JT, Lin MC, et al. 2016. Functional polymorphisms of the TLR7 and TLR8 genes contribute to Mycobacterium tuberculosis infection. Tuberculosis (Edinb) 98: 125-131.

67. Tang J, Sun M, Shi G, Xu Y, Han Y, Li X, et al. 2017. TollLike receptor 8 agonist strengthens the protective efficacy of ESAT-6 immunization to Mycobacterium tuberculosis infection. Front. Immunol. 8: 1972.

68. Hemmi H, Takeuchi O, Kawai T, Kaisho T, Sato S, Sanjo H, et al. 2000. A Toll-like receptor recognizes bacterial DNA. Nature 408: 740-745.

69. Latz E, Schoenemeyer A, Visintin A, Fitzgerald KA, Monks BG, Knetter CF, et al. 2004. TLR9 signals after translocating from the ER to CpG DNA in the lysosome. Nat. Immunol. 5: 190-198.

70. Jo EK, Yang CS, Choi CH, Harding CV. 2007. Intracellular signalling cascades regulating innate immune responses to Mycobacteria: branching out from Toll-like receptors. Cell Microbiol. 9: 1087-1098.

71. Rahman AH, Taylor DK, Turka LA. 2009. The contribution of direct TLR signaling to T cell responses. Immunol. Res. 45: 25-36.

72. Bafica A, Scanga CA, Feng CG, Leifer C, Cheever A, Sher A. 2005. TLR9 regulates Th1 responses and cooperates with
TLR2 in mediating optimal resistance to Mycobacterium tuberculosis. J. Exp. Med. 202: 1715-1724.

73. Cervantes JL, Oak E, Garcia J, Liu H, Lorenzini PA, Batra D, et al. 2019. Vitamin D modulates human macrophage response to Mycobacterium c. Tuberculosis (Edinb) 116S: S131-S137.

74. Chen Z, Wang W, Liang J, Wang J, Feng S, Zhang G. 2015. Association between toll-like receptors 9 (TLR9) gene polymorphism and risk of pulmonary tuberculosis: metaanalysis. BMC Pulm. Med. 15: 57.

75. Graustein AD, Horne DJ, Arentz M, Bang ND, Chau TT, Thwaites GE, et al. 2015. TLR9 gene region polymorphisms and susceptibility to tuberculosis in Vietnam. Tuberculosis (Edinb) 95: 190-196.

76. Bharti D, Kumar A, Mahla RS, Kumar S, Ingle H, Shankar H, et al. 2014. The role of TLR9 polymorphism in susceptibility to pulmonary tuberculosis. Immunogenetics 66: 675-681.

77. Yuk JM, Jo EK. 2014. Host immune responses to mycobacterial antigens and their implications for the development of a vaccine to control tuberculosis. Clin. Exp. Vaccine Res. 3: 155-167.

78. Geluk A, van Meijgaarden KE, Joosten SA, Commandeur S, Ottenhoff TH. 2014. Innovative strategies to identify M. tuberculosis antigens and epitopes using genome-wide analyses. Front. Immunol. 5: 256.

79. Lindestam Arlehamn CS, Lewinsohn D, Sette A, Lewinsohn D. 2014. Antigens for CD4 and CD8 T cells in tuberculosis. Cold Spring Harb. Perspect. Med. 4: a018465.

80. Moguche AO, Musvosvi M, Penn-Nicholson A, Plumlee CR, Mearns H, Geldenhuys $\mathrm{H}$, et al. 2017. Antigen availability shapes $\mathrm{T}$ cell differentiation and function during tuberculosis. Cell Host Microbe 21: 695-706.

81. Yang JD, Mott D, Sutiwisesak R, Lu YJ, Raso F, Stowell B, et al. 2018. Mycobacterium tuberculosis-specific CD4+ and $\mathrm{CD} 8+\mathrm{T}$ cells differ in their capacity to recognize infected macrophages. PLoS Pathog. 14: e1007060.

82. Commandeur S, van den Eeden SJ, Dijkman K, Clark SO, van Meijgaarden KE, Wilson L, et al. 2014. The in vivo expressed Mycobacterium tuberculosis (IVE-TB) antigen Rv2034 induces CD4(+) T-cells that protect against pulmonary infection in HLA-DR transgenic mice and guinea pigs. Vaccine 32: 3580-3588.

83. Li F, Feng L, Jin C, Wu X, Fan L, Xiong S, et al. 2018. LpqT improves mycobacteria survival in macrophages by inhibiting TLR2 mediated inflammatory cytokine expression and cell apoptosis. Tuberculosis (Edinb). 111: 57-66.

84. Su H, Zhu S, Zhu L, Huang W, Wang H, Zhang Z, et al. 2016. Recombinant lipoprotein Rv1016c derived from Mycobacterium tuberculosis is a TLR-2 ligand that induces macrophages apoptosis and inhibits MHC II antigen processing. Front. Cell. Infect. Microbiol. 6: 147.

85. Drage MG, Tsai HC, Pecora ND, Cheng TY, Arida AR, Shukla S, et al. 2010. Mycobacterium tuberculosis lipoprotein 
LprG (Rv1411c) binds triacylated glycolipid agonists of Toll-like receptor 2. Nat. Struct. Mol. Biol. 17: 1088-1095.

86. Gehring AJ, Dobos KM, Belisle JT, Harding CV, Boom WH. 2004. Mycobacterium tuberculosis LprG (Rv1411c): a novel TLR-2 ligand that inhibits human macrophage class II MHC antigen processing. J. Immunol. 173: 2660-2668.

87. Pecora ND, Gehring AJ, Canaday DH, Boom WH, Harding CV. 2006. Mycobacterium tuberculosis LprA is a lipoprotein agonist of TLR2 that regulates innate immunity and APC function. J. Immunol. 177: 422-429.

88. Shin DM, Yuk JM, Lee HM, Lee SH, Son JW, Harding CV, et al. 2010. Mycobacterial lipoprotein activates autophagy via TLR2/1/CD14 and a functional vitamin D receptor signalling. Cell. Microbiol. 12: 1648-1665.

89. Lancioni CL, Li Q, Thomas JJ, Ding X, Thiel B, Drage MG, et al. 2011. Mycobacterium tuberculosis lipoproteins directly regulate human memory $\mathrm{CD} 4(+) \mathrm{T}$ cell activation via Tolllike receptors 1 and 2. Infect. Immun. 79: 663-673.

90. Sanchez A, Espinosa P, Garcia T, Mancilla R. 2012. The $19 \mathrm{kDa}$ Mycobacterium tuberculosis lipoprotein (LpqH) induces macrophage apoptosis through extrinsic and intrinsic pathways: a role for the mitochondrial apoptosis-inducing factor. Clin. Dev. Immunol. 2012: 950503.

91. Liu L, Liu J, Niu G, Xu Q, Chen Q. 2015. Mycobacterium tuberculosis 19-kDa lipoprotein induces Toll-like receptor 2dependent peroxisome proliferator-activated receptor gamma expression and promotes inflammatory responses in human macrophages. Mol. Med. Rep. 11: 2921-2926.

92. Lopez M, Sly LM, Luu Y, Young D, Cooper H, Reiner NE. 2003. The 19-kDa Mycobacterium tuberculosis protein induces macrophage apoptosis through Toll-like receptor-2. J. Immunol. 170: 2409-2416.

93. Chen ST, Li JY, Zhang Y, Gao X, Cai H. 2012. Recombinant MPT83 derived from Mycobacterium tuberculosis induces cytokine production and upregulates the function of mouse macrophages through TLR2. J. Immunol. 188: 668-677.

94. Wang L, Zuo M, Chen H, Liu S, Wu X, Cui Z, et al. 2017. Mycobacterium tuberculosis lipoprotein MPT83 induces apoptosis of infected macrophages by activating the TLR2/ p38/COX-2 signaling pathway. J. Immunol. 198: 4772-4780.

95. Elass E, Aubry L, Masson M, Denys A, Guerardel Y, Maes E, et al. 2005. Mycobacterial lipomannan induces matrix metalloproteinase-9 expression in human macrophagic cells through a Toll-like receptor 1 (TLR1)/TLR2- and CD14dependent mechanism. Infect. Immun. 73: 7064-7068.

96. Gilleron M, Nigou J, Nicolle D, Quesniaux V, Puzo G. 2006. The acylation state of mycobacterial lipomannans modulates innate immunity response through toll-like receptor 2. Chem. Biol. 13: 39-47.

97. Puissegur MP, Lay G, Gilleron M, Botella L, Nigou J, Marrakchi $\mathrm{H}$, et al. 2007. Mycobacterial lipomannan induces granuloma macrophage fusion via a TLR2-dependent,
ADAM9- and beta1 integrin-mediated pathway. J. Immunol. 178: 3161-3169.

98. Tapping RI, Tobias PS. 2003. Mycobacterial lipoarabinomannan mediates physical interactions between TLR1 and TLR2 to induce signaling. J. Endotoxin Res. 9: 264-268.

99. Bansal K, Elluru SR, Narayana Y, Chaturvedi R, Patil SA, Kaveri SV, et al. 2010. PE_PGRS antigens of Mycobacterium tuberculosis induce maturation and activation of human dendritic cells. J. Immunol. 184: 3495-3504.

100. Chaturvedi R, Bansal K, Narayana Y, Kapoor N, Sukumar N, Togarsimalemath SK, et al. 2010. The multifunctional PE_PGRS11 protein from Mycobacterium tuberculosis plays a role in regulating resistance to oxidative stress. J. Biol. Chem. 285: 30389-30403.

101. Basu S, Pathak SK, Banerjee A, Pathak S, Bhattacharyya A, Yang Z, et al. 2007. Execution of macrophage apoptosis by PE_PGRS33 of Mycobacterium tuberculosis is mediated by Toll-like receptor 2-dependent release of tumor necrosis factor-alpha. J. Biol. Chem. 282: 1039-1050.

102. Palucci I, Camassa S, Cascioferro A, Sali M, Anoosheh S, Zumbo A, et al. 2016. PE_PGRS33 contributes to Mycobacterium tuberculosis entry in macrophages through interaction with TLR2. PLoS One 11: e0150800.

103. Vani J, Shaila MS, Trinath J, Balaji KN, Kaveri SV, Bayry J. 2013. Mycobacterium tuberculosis cell wall-associated Rv3812 protein induces strong dendritic cell-mediated interferon gamma responses and exhibits vaccine potential. J. Infect. Dis. 208: 1034-1036.

104. Huang Y, Wang Y, Bai Y, Wang ZG, Yang L, Zhao D. 2010. Expression of PE_PGRS 62 protein in Mycobacterium smegmatis decrease mRNA expression of proinflammatory cytokines IL-1beta, IL-6 in macrophages. Mol. Cell. Biochem. 340: 223-229.

105. Bhat KH, Chaitanya CK, Parveen N, Varman R, Ghosh S, Mukhopadhyay S. 2012. Proline-proline-glutamic acid (PPE) protein Rv1168c of Mycobacterium tuberculosis augments transcription from HIV-1 long terminal repeat promoter. J. Biol. Chem. 287: 16930-16946.

106. Ahmed A, Dolasia K, Mukhopadhyay S. 2018. Mycobacterium tuberculosis PPE18 protein reduces inflammation and increases survival in animal model of sepsis. J. Immunol. 200: 3587-3598.

107. Nair S, Ramaswamy PA, Ghosh S, Joshi DC, Pathak N, Siddiqui I, et al. 2009. The PPE18 of Mycobacterium tuberculosis interacts with TLR2 and activates IL-10 induction in macrophage. J. Immunol. 183: 6269-6281.

108. Tiwari B, Soory A, Raghunand TR. 2014. An immunomodulatory role for the Mycobacterium tuberculosis region of difference 1 locus proteins PE35 (Rv3872) and PPE68 (Rv3873). FEBS J. 281: 1556-1570.

109. Su H, Kong C, Zhu L, Huang Q, Luo L, Wang H, et al. 2015. PPE26 induces TLR2-dependent activation of macrophages and drives Th1-type T-cell immunity by 
triggering the cross-talk of multiple pathways involved in the host response. Oncotarget 6: 38517-38537.

110. Deng W, Li W, Zeng J, Zhao Q, Li C, Zhao Y, et al. 2014. Mycobacterium tuberculosis PPE family protein Rv1808 manipulates cytokines profile via co-activation of MAPK and NF-kappaB signaling pathways. Cell. Physiol. Biochem. 33: $273-288$.

111. Su H, Zhang Z, Liu Z, Peng B, Kong C, Wang H, et al. 2018. Mycobacterium tuberculosis PPE60 antigen drives Th1/ Th17 responses via Toll-like receptor 2-dependent maturation of dendritic cells. J. Biol. Chem. 293: 10287-10302.

112. Parveen N, Varman R, Nair S, Das G, Ghosh S, Mukhopadhyay S. 2013. Endocytosis of Mycobacterium tuberculosis heat shock protein 60 is required to induce interleukin-10 production in macrophages. J. Biol. Chem. 288: 24956-24971.

113. Khan N, Alam K, Mande SC, Valluri VL, Hasnain SE, Mukhopadhyay S. 2008. Mycobacterium tuberculosis heat shock protein 60 modulates immune response to PPD by manipulating the surface expression of TLR2 on macrophages. Cell. Microbiol. 10: 1711-1722.

114. Singh PP, LeMaire C, Tan JC, Zeng E, Schorey JS. 2011. Exosomes released from $M$. tuberculosis infected cells can suppress IFN-gamma mediated activation of naive macrophages. PLoS One. 6: e18564.

115. Bednarska K, Kielbik M, Sulowska Z, Dziadek J, Klink M. 2014. Cholesterol oxidase binds TLR2 and modulates functional responses of human macrophages. Mediators Inflamm. 2014: 498395.

116. Byun EH, Kim WS, Kim JS, Jung ID, Park YM, Kim HJ, et al. 2012. Mycobacterium tuberculosis Rv0577, a novel TLR2 agonist, induces maturation of dendritic cells and drives Th1 immune response. FASEB J. 26: 2695-2711.

117. Madan-Lala R, Peixoto KV, Re F, Rengarajan J. 2011. Mycobacterium tuberculosis Hip1 dampens macrophage proinflammatory responses by limiting toll-like receptor 2 activation. Infect. Immun. 79: 4828-4838.

118. Madan-Lala R, Sia JK, King R, Adekambi T, Monin L, Khader SA, et al. 2014. Mycobacterium tuberculosis impairs dendritic cell functions through the serine hydrolase Hip1. J. Immunol. 192: 4263-4272.

119. Bandyopadhyay U, Chadha A, Gupta P, Tiwari B, Bhattacharyya K, Popli S, et al. 2017. Suppression of Tolllike receptor 2-mediated proinflammatory responses by Mycobacterium tuberculosis protein Rv3529c. J. Leukoc Biol. 102: $1249-1259$.

120. Kumar A, Singh SM, Singh R, Kaur J. 2017. Rv0774c, an iron stress inducible, extracellular esterase is involved in immune-suppression associated with altered cytokine and TLR2 expression. Int. J. Med. Microbiol. 307: 126-138.

121. Liu Y, Li JY, Chen ST, Huang HR, Cai H. 2016. The rLrp of Mycobacterium tuberculosis inhibits proinflammatory cytokine production and downregulates APC function in mouse macrophages via a TLR2-mediated PI3K/Akt pathway activation-dependent mechanism. Cell. Mol. Immunol. 13: 729-746.

122. Gao X, Wu C, He W, Wang X, Li Y, Wang Y, et al. 2019. DosR antigen Rv1737c induces activation of macrophages dependent on the TLR2 pathway. Cell. Immunol. 344: 103947.

123. Peddireddy V, Doddam SN, Qureshi IA, Yerra P, Ahmed N. 2016. A putative nitroreductase from the DosR regulon of Mycobacterium tuberculosis induces pro-inflammatory cytokine expression via TLR2 signaling pathway. Sci. Rep. 6: 24535.

124. Yihao D, Hongyun H, Maodan T. 2015. Latency-associated protein Rv2660c of Mycobacterium tuberculosis augments expression of proinflammatory cytokines in human macrophages by interacting with TLR2. Infect. Dis. (Lond) 47: 168-177.

125. Kim WS, Kim JS, Cha SB, Kim H, Kwon KW, Kim SJ, et al. 2016. Mycobacterium tuberculosis Rv3628 drives Th1-type T cell immunity via TLR2-mediated activation of dendritic cells and displays vaccine potential against the hypervirulent Beijing K strain. Oncotarget 7: 24962-24982.

126. Kumar A, Lewin A, Rani PS, Qureshi IA, Devi S, Majid M, et al. 2013. Dormancy associated translation inhibitor (DATIN/Rv0079) of Mycobacterium tuberculosis interacts with TLR2 and induces proinflammatory cytokine expression. Cytokine 64: 258-264.

127. Saraav I, Singh S, Pandey K, Sharma M, Sharma S. 2017. Mycobacterium tuberculosis MymA is a TLR2 agonist that activate macrophages and a TH1 response. Tuberculosis (Edinb). 106: 16-24.

128. Prados-Rosales R, Baena A, Martinez LR, Luque-Garcia J, Kalscheuer R, Veeraraghavan U, et al. 2011. Mycobacteria release active membrane vesicles that modulate immune responses in a TLR2-dependent manner in mice. J. Clin. Invest. 121: 1471-1483.

129. Ko A, Wui SR, Ryu JI, Lee YJ, Hien DTT, Rhee I, et al. 2018. Potentiation of Th1-type immune responses to Mycobacterium tuberculosis antigens in mice by cationic liposomes combined with De-O-Acylated Lipooligosaccharide. J. Microbiol. Biotechnol. 28: 136-144.

130. Sun F, Oh S, Kim J, Kato T, Kim HJ, Lee J, et al. 2017. Enhanced internalization of Macromolecular drugs into Mycobacterium smegmatis with the assistance of silver nanoparticles. J. Microbiol. Biotechnol. 27: 1483-1490.

131. Pennini ME, Pai RK, Schultz DC, Boom WH, Harding CV. 2006. Mycobacterium tuberculosis 19-kDa lipoprotein inhibits IFN-gamma-induced chromatin remodeling of MHC2TA by TLR2 and MAPK signaling. J. Immunol. 176: 4323-4330.

132. Choi HG, Choi S, Back YW, Park HS, Bae HS, Choi CH, et al. 2016. Mycobacterium tuberculosis Rv2882c protein induces activation of macrophages through TLR4 and exhibits vaccine potential. PLoS One 11: e0164458. 
133. Kim K, Sohn H, Kim JS, Choi HG, Byun EH, Lee KI, et al. 2012. Mycobacterium tuberculosis Rv0652 stimulates production of tumour necrosis factor and monocytes chemoattractant protein-1 in macrophages through the Toll-like receptor 4 pathway. Immunology 136: 231-240.

134. Lee SJ, Shin SJ, Lee MH, Lee MG, Kang TH, Park WS, et al. 2014. A potential protein adjuvant derived from Mycobacterium tuberculosis Rv0652 enhances dendritic cellsbased tumor immunotherapy. PLoS One 9: e104351.

135. Stewart GR, Snewin VA, Walzl G, Hussell T, Tormay P, O'Gaora P, et al. 2001. Overexpression of heat-shock proteins reduces survival of Mycobacterium tuberculosis in the chronic phase of infection. Nat. Med. 7: 732-737.

136. Young DB, Garbe TR. 1991. Heat shock proteins and antigens of Mycobacterium tuberculosis. Infect. Immun. 59: 3086-3093.

137. Bulut Y, Michelsen KS, Hayrapetian L, Naiki Y, Spallek R, Singh M, et al. 2005. Mycobacterium tuberculosis heat shock proteins use diverse Toll-like receptor pathways to activate pro-inflammatory signals. J. Biol. Chem. 280: 20961-20967.

138. Kim WS, Jung ID, Kim JS, Kim HM, Kwon KW, Park YM, et al. 2018. Mycobacterium tuberculosis GrpE, A heat-shock stress responsive chaperone, promotes Th1-biased $\mathrm{T}$ cell immune response via TLR4-Mediated Activation of dendritic cells. Front. Cell. Infect. Microbiol. 8: 95.

139. Kim JS, Kim WS, Choi HG, Jang B, Lee K, Park JH, et al. 2013. Mycobacterium tuberculosis RpfB drives Th1-type $\mathrm{T}$ cell immunity via a TLR4-dependent activation of dendritic cells. J. Leukoc Biol. 94: 733-749.

140. Choi S, Choi HG, Shin KW, Back YW, Park HS, Lee JH, et al. 2018. Mycobacterium tuberculosis protein Rv3841 activates dendritic cells and contributes to a T Helper 1 immune response. J. Immunol. Res. 2018: 3525302.

141. Lin J, Chang Q, Dai X, Liu D, Jiang Y, Dai Y. 2019. Early secreted antigenic target of 6-kDa of Mycobacterium tuberculosis promotes caspase-9/caspase-3-mediated apoptosis in macrophages. Mol. Cell. Biochem. 457: 179-189.

142. Jang AR, Choi JH, Shin SJ, Park JH. 2018. Mycobacterium tuberculosis ESAT6 induces IFN-beta gene expression in Macrophages via TLRs-mediated signaling. Cytokine 104: 104-109.

143. Samten B, Wang X, Barnes PF. 2009. Mycobacterium tuberculosis ESX-1 system-secreted protein ESAT-6 but not CFP10 inhibits human T-cell immune responses. Tuberculosis (Edinb) 89 Suppl 1: S74-76.

144. Lim YJ, Choi JA, Lee JH, Choi $\mathrm{CH}$, Kim HJ, Song $\mathrm{CH}$. 2015. Mycobacterium tuberculosis 38-kDa antigen induces endoplasmic reticulum stress-mediated apoptosis via tolllike receptor 2/4. Apoptosis 20: 358-370.

145. Park HS, Back YW, Shin KW, Bae HS, Lee KI, Choi HG, et al. 2019. Mycobacterium tuberculosis Rv3463 induces mycobactericidal activity in macrophages by enhancing phagolysosomal fusion and exhibits therapeutic potential. Sci. Rep. 9: 4246.

146. Faridgohar M, Nikoueinejad H. 2017. New findings of Tolllike receptors involved in Mycobacterium tuberculosis infection. Pathog. Glob. Health. 111: 256-264.

147. Weeratunga P, Herath TUB, Kim TH, Lee HC, Kim JH, Lee $\mathrm{BH}$, et al. 2017. Dense granule protein-7 (GRA-7) of Toxoplasma gondii inhibits viral replication in vitro and in vivo. J. Microbiol. 55: 909-917.

148. Yang CS, Yuk JM, Lee YH, Jo EK. 2016. Toxoplasma gondii GRA7-induced TRAF6 activation contributes to host protective immunity. Infect. Immun. 84: 339-350.

149. Kim YR, Kim JS, Yun JS, Kim S, Kim SY, Jang K, et al. 2018. Toxoplasma gondii GRA8 induces ATP5A1-SIRT3mediated mitochondrial metabolic resuscitation: a potential therapy for sepsis. Exp. Mol. Med. 50(3): e464.

150. Shi L, Eugenin EA, Subbian S. 2016. Immunometabolism in Tuberculosis. Front. Immunol. 7: 150. 